\title{
Model Prefaces from Russian Literature
}

\section{1

\section{I}

\section{AUTHENTIC AUTHORIAL INTRODUCTIONS}

We begin our examination of model prefaces with the type of introduction-authentic authorial discourse-Dostoevsky eschewed until the end of his career when writing fiction for The Diary of a Writer and when composing the opening to The Brothers Karamazov. In all other instances, Dostoevsky shied away from appearing to speak in his own voice in his prefaces. There are reasons for this that we shall address when we turn to his late work. It serves our purposes now, however, to examine models of direct authorial address in representative examples of early nineteenth-century Russian prose.

To give us a jumpstart on that century, we turn first to Vasily Narezhny (1780-1825) and his foreword to his once-popular A Russian Gil Blas (1814). The introduction is presented in his own words and from his own authorial position: "The most excellent work of Lesage, known under the title The Adventures of Gil Blas de Santillana, has brought and continues to bring as much pleasure and utility to the reading public as it has honor and surprise to its publisher." ${ }^{1}$ Finished with the bombast, Narezhny continues by articulating his rationale for writing: "France and Germany have their own heroes [of this type] whose

1 I have translated the passage faithfully to reflect Narezhny's syllepsis. I believe what he wished to say was "... to the honor of the author and to the surprise of his publisher.” V. V. Narezhnyi, Izbrannye sochineniia I (Moscow: Khudlit, 1956), 43. 
adventures fall under the titles A French Gil Blas and A German Gil Blas. And for this reason I have taken it upon myself, following these examples, to publish this new work of mine under this well-known title and thus to unburden those [had I entitled the work differently] who would otherwise have labored to discover with whom I, in this composition, might be compared." ${ }^{2}$ Narezhny has fun with his readers, but also with Alain René Lesage, a Frenchman who inexplicably, for Narezhny, chose to situate his hero in Spain: "For Russian folk I have fashioned a Russian personage, considering it so much more proper to take up the business of a fellow countryman rather than that of a foreigner. Why Lesage could not have done this one can only guess." ${ }^{3}$

Genette notes that the most common function of the preface is to identify the work's genre. ${ }^{4}$ Here we see Narezhny engaged in that task. His work is a picaresque. But, he also goes to some length to poke fun at his reader, whose tastes, he anticipates, may not be satisfied by a Russian Gil Blas. It turns out, too, that he had more than the public's taste to contend with. Generations of censorship kept his Russian Gil Blas from unexpurgated publication for a very long time indeed-until $1938 .^{5}$

Readers and censors aside, there is the matter of the literary model, Lesage. Narezhny's query of Lesage's intent in situating his hero in Spain hints at the superiority of his (Narezhny's) own work vis-à-vis the model narrative. In the inchoate Romantic Age in Russia, this was no small matter, for nativeness (narodnost') was becoming all the rage. Common as it might be for authors of imitative works, Narezhny's need to vault himself above Lesage underscores a level of tension, of insecurity, relative to his own achievement. Never mind surpassing it; does Narezhny's hold up to the original? Furthermore, there is a degree of anxiety to be ascertained, too, in Narezhny's own identity relative to his work-a Ukrainian writing a Russian Gil Blas into Russian literary history, while simultaneously chastising Lesage for placing his hero in a country other than Lesage's France. Clearly, more goes on in prefaces than the mere introduction of genre. It is also a locus of emotion, where

2 Narezhnyi, Izbrannye sochineniia, 43.

Narezhnyi, Izbrannye sochineniia, 44.

Genette, Paratexts, 222.

5 Narezhnyi, Izbrannye sochiineniia II, 615-617. 
the author's sometimes hidden, sometimes overt, desires as well as his anxieties are encoded.

It is the locus, too, of many a scrape and bow. Even sycophancy has a place. Faddei Bulgarin's preface to his re-make of Narezhny's re-make of Lesage's Gil Blas was published in 1829. (It first appeared in serial form in the mid-1820s.) The foreword to Ivan Ivanovich Vyzhigin, Bulgarin's vain attempt at imitation, is cast in the form of a dedicatory letter addressed to "His Highness [Count] Arsenii Andreevich Zakrevskii." This is not someone whose name will pop up soon in a history of Russia, but someone who, for Bulgarin, had pull in the right places—at Court: "Twenty years have passed ..." Bulgarin writes bombastically, "since I first saw you on the field of battle in Finland when the unforgettable Count Nikolai Mikhailovich Kamensky led us to victory after victory and together with us overcame incredible challenges ..." ${ }^{6}$ Bulgarin then turns to genre; his work is a satire. He cites Peter the Great's instruction for writing in this genre and rolls out the shortest of short lists of Russian authors who have inspired him in his endeavor, Prince Antiokh Kantemir and Catherine the Great. ${ }^{7}$

Despite having this most distinguished and excellent cover, Bulgarin nonetheless foresees that his readers will be offended by his work. He reinvents the jock wisdom "A strong defense is a strong offense": "[My] Vyzhigin will not be appreciated by people who take every truth loudly proclaimed as an act of self will [svoevol'stvo], every exposure of abuse an act of ill intent ..." ${ }^{8} \mathrm{He}$ casts himself here as radical and heroic-he will man up against the barbs and jibes sent to afflict him.

Bulgarin is not an author whose name is associated with willfulness, with challenges to authority, or with attempts at overturning the status quo. He serves grand figures of authority-we surely noticed his reference to Catherine II-not to challenge them, but to bask in the glory of their mere mention. And also to underscore his obeisance to them: "Well-intentioned people of all classes feel to the full extent the

6 Faddei Bulgarin, Sochineniia (Moscow: Sovremennik, 1990), 24.

7 Bulgarin, Sochineniia, 25. Antiokh Dmitrievich Kantemir (1709-1744), ambassador to England and France, wrote nine satires in which Russian backwardness vis-à-vis Europe was taken to task. He had trouble with the censors and his satires were first published posthumously in 1749, but only in French translation. They appeared in Russian in the second half of the eighteenth century.

8 Bulgarin, Sochineniia, 25. 
magnanimous intentions of our wise rulers and are prepared to the extreme to serve the greatest good. The Bureau of the Censor, having been ratified on the twenty-second of April 1828, is a durable memorial to the love of Enlightenment and to the Eternal Truth, beloved by us all, and propagated by Our Very Orthodox Monarch—a memorial worthy of our century and of the greatness of Russia!" ${ }^{9}$ Bulgarin does not mask his desire to have Zakrevskii represent him in the higher echelons of society. We note, too, that Bulgarin (pity him) does not belong to those higher echelons. But he longs to belong. His rhetoric encodes insecurity, hope, and strategy.

Modesty is absent in Bulgarin's remarks: "Thanks be to God, we still have authentic Russian Nobles of Old [vel'mozhi] among us who through their service to the Crown have acquired the right to approach the Sacred Steps of the Throne." ${ }^{10}$ Bulgarin is not shy in his efforts to align himself with these Nobles of Old. (He flatters Zakrevskii that he is one.) In fact, in an act of performative rhetoric, he claims himself to be one of them, too, if only literarily, for he distinguishes himself heroically on the page as much as the vel'mozhi have by the sword: "Will my readers enjoy the simplicity of the plot movement and of the narration? I hardly know. Let them forgive me any imperfection [in my tale] for the sake of my honorable goal [in writing it], but [let them also recognize] that mine is the first original Russian novel in this genre." ${ }^{11}$ Narezhny raises an eyebrow.

Bulgarin attacks the current state of literary arts in Russia (the done thing in the early nineteenth century), roundly assaulting the incapacities of authors, readers, and critics alike. That is to say, he indicts the entire complex of individuals who make up these key components of the institutions of literature. His most stinging barbs are aimed at critics:

I haven't focused on contemporary [criticism in] my satire, for in our day [literature] needs more assistance than opposition-it is not yet of sufficient age and it is burdened by many ills that are inimical to good morals [to warrant my barbs]. Few are the number of the literarily engaged among us. They do not comprise a distinct class such as

9 Bulgarin, Sochineniia, 26.

10 Bulgarin, Sochineniia, 27.

11 Bulgarin, Sochineniia, 28. 
they do in other countries. ${ }^{12}$ [Critics] do not address what is harmful [in their essays], but instead make the odd remark about literary art and then denigrate worthy writers. Their opinions carry no weight with the public, but bring shame to the most biased and immature of their ilk. I [leave] them in peace—one doesn't beat a sleeping dog. ${ }^{13}$

Bulgarin's insecurities are glaring in these remarks. Anticipating criticism of his re-issued novel, and not without cause given the blows he had received during its serial publication, Bulgarin attempts to shore up his case. In his preface, therefore, he kisses up and kicks down. He flatters Zakrevsky and chastises his opponents. This was his signature in literary society.

Introductions bring literary debate to the fore. In Bulgarin's instance, his preface highlights unwittingly a raw ambition undergirded by personal, professional, and cultural insecurity. As much as Narezhny was anxious about writing as a Ukrainian in the dominant Russian culture, so, too, was the Pole, Faddei Bulgarin. A renowned stooge of Nicholas I's infamous creation, the Third Section (the secret police), Bulgarin suffered for his national origins and social status in Russia. He sought good cover. $^{14}$

If Bulgarin in his introduction was hard on his critics and literary opponents, he was kinder to his readers. The same can't be said of Mikhail Lermontov who began publishing pieces of A Hero of Our Time within a few years of Ivan Vyzhigin's publication. When the novel, considered the first novel of psychological realism in Russian literature, first appeared in print in 1841 , it contained no preface. It sold

12 Bulgarin mistakes class for profession, a normative thing to do in the Age of Pushkin, but less so as the third decade commenced. See William Mills Todd III, Literature and Society in the Age of Pushkin (Cambridge, MA: Harvard University Press, 1986), 10-105.

13 Bulgarin, Sochineniia, 28.

14 See Sidney Monas, The Third Section: Police and Society under Nicholas I (Cambridge, MA: Harvard University Press, 1961). “[Bulgarin's] own profitable literary activities depended upon the support of the Third Section of His Majesty's Imperial Chancery, which helped finance Bulgarin's newspaper, protected him from other censorship organs, restrained his literary competitors, and even sought promotions for him from the Ministry of Education" (Todd, Literature and Society, 75). For more on Bulgarin's origins and his role as informer, see Joe Peschio, The Poetics of Impudence and Intimacy in the Age of Pushkin (Madison: The Wisconsin University Press, 2012), 110-113. 
out quickly, and in 1842 a second edition was published. This time it contained a word from the author, one written in response to what the critics had said about the first edition.

Lermontov's authentic authorial preface was akin to Bulgarin's in that it was published only in subsequent editions. Readers and critics get scathing treatment in equal measure. But, unlike Bulgarin's preface, Lermontov's lacks a sycophantic note. In fact, the preface is not out to make friends and influence people. It comes dripping jet black from Lermontov's bilious pen. Readers receive the first jab:

In every book the preface is the first and also the last thing. It serves either to explain the purpose of the work or to justify it and answer criticism. But readers are generally not concerned with moral purposes or with attacks in reviews, and in result, they do not read prefaces. It is a pity that this should be so, particularly in our country. Our public is still so young and naïve that it fails to understand a fable unless it finds a lesson at its end. ${ }^{15}$

Lermontov's pugilistic stance is not unusual for him. He attacks the premises of prefaces-genre identification, self-justification, selfdefense- as the paltry concerns of lesser critics and faint-hearted writers. These are not the concerns of readers whom he imagines sweeping

15 M. Iu. Lermontov, Polnoe sobranie sochinenii $v$ piati tomakh V (Moscow: Akademiia, 1936-1952), 30; Mikhail Lermontov, A Hero of Our Time, trans. Vladimir and Dmitry Nabokov (Ann Arbor: Ardis, 1988), 1. (Subsequent citations provide page numbers, first for the English translation, then for the Russian. This convention holds for the remainder of my study, save in those instances where it is only essential to cite the English translation.) In saying that prefaces are first and last things, he means that they are most often written last, but placed first. He is at least correct in regard to A Hero of Our Time and to the contemporaneous Russian Nights (1844) by Prince Vladimir Odoevsky, who wrote an introduction to his tales later (for his collected works) even though he had already attached one to the original publication (Sochineniia $v$ dvukh tomakh 1 [Moscow: Khudlit, 1981], 31-33); Vladimir F. Odoevsky, Russian Nights, trans. Olga Olienikov and Ralph E. Matlaw (New York: E. P. Dutton \& Co., 1965), 221-234. Cf. Narezhny's introduction, which comes first, but was hardly written last. The same is generally true of Dostoevsky's forewords; they are rarely, if ever, written last. They are attached to the first installment of his serialized fiction, i.e., long before he had written much, if any, of the narrative's later parts. Exceptions come in his The Diary of a Writer. See Todd, “'To Be Continued': Dostoevsky's Evolving Poetics of Serialized Publication," Dostoevsky Studies 18 (2014): 27, 30-31. 
past introductions as so much uninteresting flotsam on the messy shore of clean story. Lermontov's audience, however, does not escape his scorn. They come in for harsh treatment as gaping rubes: "[Our readers miss] a humorous point and [do] not feel irony; they are, quite simply put, brought up badly. . . . Our public resembles a provincial who, upon overhearing the conversation of two diplomats belonging to two warring Courts, is convinced that each envoy is betraying his government in the interest of a most tender mutual friendship." 16 Despite his condescension toward the general reading public, which was small but burgeoning at the time, Lermontov nevertheless provides ample opportunity for a projected ideal reader to participate with him in his jests. ${ }^{17}$ Through the metaphor of diplomatic niceties between warring parties he suggests his preferred relationship with a public made up of naïve readers and inept critics. But with intimates and kindred spirits he imagines quite different relations. ${ }^{18}$

Alas, Lermontov is hoisted on his own petard. His aggressiveness merely obscures the similarity between his preface and those of his opponents. A Hero of Our Time has been subjected to mindless interpretation, he claims. It has been misread, and his intentions in writing the novel have been mistaken. So, Lermontov defends himself from the mindlessness and the naïveté of his detractors by engaging in the three rhetorical forms he denigrates at the outset-purpose, self-justification, and defense. ${ }^{19}$

The present book has only recently suffered from the unfortunate faith that certain readers and even certain reviewers have in the literal meaning of words. Some were dreadfully offended, quite in earnest, that such an immoral person as the hero of our time should be set as a model to them; others very subtly remarked that the author had drawn

16 Lermontov, Hero, $1 ; 185$.

17 Donald Fanger, The Creation of Gogol (Cambridge: Harvard University Press, 1979), 24-44.

18 For an expanded treatment of authors targeting distinct audiences, see Peschio, Poetics of Impudence, 34-59.

19 Lermontov exaggerates the degree to which his work was unappreciated. At the time there were many a positive review, some quite astute. His arrows were aimed only at his detractors, but Lermontov overstates their representativeness. To examine some of the earliest reviews of the novel, see my Lermontov's "A Hero of Our Time”: A Critical Companion (Evanston: Northwestern University Press, 2002), 145-195. 
his own portrait and the portraits of his acquaintances ... What an old and paltry jest! But apparently Russia is created in such a way that everything in it changes for the better, except this sort of nonsense. With us the most fantastic of all fairy tales would hardly escape the reproach of being meant as some personal insult. ${ }^{20}$

Lermontov's sword is double-edged. On the one hand he argues that forewords engage in the task, useless to the general public, of selfdefense. Then, on the other hand, he roundly defends his work from what he has misconstrued as injudicious readings of his novel. Furthermore, Lermontov chastises reviewers and readers "of a certain type" for taking as a slight the depiction of his protagonist and of the dramatis personae surrounding him. Lermontov, in equal measure, takes personally the barbs aimed at him and his novel in the reviews.

Lermontov gives with one hand and takes with the other. Having poked fun at those who take personal offense at the portrait of Pechorin, claiming that they read out of false vanity, he next asserts that they should indeed take offense, that he has aimed his protagonist at society, like a fist into its face. Can he then claim that there is no moral purpose to his novel? Hardly, for in presenting an amoral hero to the public for their censure, he simply flips the coin on how moral lessons are constituted in fiction:

You will say that morality gains nothing from this. I beg your pardon. People have been fed enough sweetmeats; it has given them indigestion: they need some bitter medicine, some caustic truths. However, do not think after this that the author of this book ever had the proud dream of becoming a reformer of mankind's vices. The Lord preserve him from such benightedness! He merely found it amusing to draw modern man such as he understood him, such as he met him-too often, unfortunately, for him and you. Suffice it that the disease has been pointed out; goodness knows how to cure it. ${ }^{21}$

Lermontov overtly disavows (but covertly asserts) the moral intent of his depiction of "the vices of our generation." He will not accept the mantle of prophet that might be placed on the likes of those who wish to enlighten the public and edify them through art-he will leave that role to the likes of Bulgarin. However, identifying one of the purposes

20 Lermontov, Hero, 1-2; 185-186.

21 Lermontov, Hero, 2; 186. 
of A Hero of Our Time, Lermontov aligns himself with those who would indeed edify and instruct through art. Deny the role as he might, he assumes it nonetheless. Lermontov had a choice to publish his late authorial introduction or to refrain from doing so. He didn't restrain himself. It's a fool's game, as he knows, for it is not up to him alone to decide whether he is a moralist or not. A Hero of Our Time puts the decision into others' hands, and he resents it. As a result, his preface becomes a house divided against itself.

Lermontov's example suggests yet again that prefaces, whether in the hands of epigones or masters, not only perform diverse servicesgenre identification, self-justification, defense against anticipated criticism-but also form a shaky ground on which to stand, even for the wary. To summarize from our handful of examples, the functions of authentic authorial introductions are many, the voices cast in them diverse, their purposes broad, their projected readerships disparate, and their authorial intentions sometimes quite divergent. In all of the cases we have so far examined, the configuration of author, text, reader, critic, and publisher gets modified on the basis of each author's conscious or unconscious anxieties and concerns. In more or less direct ways, the author who pens the preface places a self-generated definition on how each party is to play his or her role. Lermontov would have his reader be as keen and wary as he. Bulgarin would have his reader be grateful to him for his labors and helpful to him in opening doors to power, security, and financial reward. Narezhny would only have the reader accept him as a genuine Russifier of European literary models.

Each author's preface demonstrates that much is left in the hands of the audience. Once the work is set loose into the public, some idea of the author emerges beyond the writer's capacity to control. Readers collectively gain a rather high degree of autonomy in fixing the meanings of the text, or, alternatively, in realizing the potential meanings the writer has made available in his or her text. The circumstances under which works are evaluated become problematic. Narezhny prompts his readers' responses, but can hardly be assured they will be forthcoming. Bulgarin focuses on the mediators of the public's literary tastes and attempts to bypass them through appeals to higher authorities who might fix the value of his work in accord with his desires. Lermontov rails at the whole circumstance of miscommunication via literary activity and rejects any 
endeavor to pigeonhole him and his novel. But he unintentionally cuts himself as he thrusts at his detractors. What these authors, perhaps all authors, long for are ideal readers who conform completely to the projected reader the author wishes them to be: "My audience grasps completely what I intended."

Better yet to have readers aid the author in the constitution of the text itself. How then could they possibly complain? This notion is our starting point in examining the last of our examples of authentic authorial prefaces. In this instance we turn to Nikolai Gogol, whose foreword, published with the second edition of his Dead Souls in 1846, is a glaring, perhaps even tragic example of an author's attempt in a foreword to have readers conform to his ideal.

Gogol's novel was first published in 1841 to wide acclaim. It was hailed as a phenomenon unlike anything encountered previously in Russian literature. But it was not enough for Gogol. He was not satisfied with his accomplishment and wished for the moral, spiritual and social transformation of his reader. Gogol sought, through the mediation of the text, to establish a complete unity with his audience.

Gogol's concern over relations with his readers was acute. It is significant that his fiction is loaded with prefaces. He rarely did without them. They are a locus for the demonstration of his anxieties as a writer. ${ }^{22}$ For example, even after the success of his Dead Souls had been thoroughly secured for posterity, he felt compelled to add an introduction to the second edition of the novel. It is a late authentic authorial preface, unique in how deeply troubled the author was in his attempt to generate, if not force, an ideal response to his already well-received novel. For Gogol that ideal consisted in the formation of a complete unity between author and reader, a unity that would inevitably lead to personal renewal and moral regeneration: "Reader, whosoever or wheresoever you be, and whatsoever be your station-whether that of a member of the higher ranks of society or that of a member of the plainer walks of life-I beg of you, if God shall have given you any skill

22 Bojanowska treats the tensions that lurk in Gogol's prefaces, particularly those he shared with Narezhny, both being Ukrainians writing for a Russian reading public. See Edyta M. Bojanowska, Nikolai Gogol: Between Ukrainian and Russian Nationalism (Cambridge: Harvard University Press, 2007), 37-88. 
in letters, and my book shall fall into your hands, to extend to me your assistance." 23

Gogol here engages a literary convention, by his time entirely tritehe seeks his readers' forbearance, etc., etc. But the preface turns out to be more than a cliché. In fact, it is something we should worry about on Gogol's behalf, for he wishes the reader to be more than receptive to his tale, kindly disposed toward it, enthusiastic about it. He asks readers to participate in it, help constitute missing parts, more specifically, to provide him with examples from their lives to underscore the novel's verisimilitude. He would then add their comments when revising the work for republication in the future:

I beg of you not to deprive me of your comments, seeing that it cannot be that, should you read my book with attention, you will have nothing to say at some point therein. For example, how excellent it would be if some reader who is sufficiently rich in experience and the knowledge of life to be acquainted with the sort of characters which I have described herein would annotate in detail the book, without missing a single page, and undertake to read it precisely as though, laying pen and paper before him, he were first to peruse a few pages of the work, and then to recall his own life and the lives of folk with whom he has come in contact, and everything which he has seen with his own eyes or has heard of from others, and to proceed to annotate, in so far as may tally with his own experience or otherwise, what is set forth in the book, and to jot down the whole exactly as it stands pictured to his memory, and lastly, to send me the jottings as they may issue from his pen, and to continue so doing until he has covered the entire work! ${ }^{24}$

The length of Gogol's second sentence surely suggests the extent of his anxieties about the reception of his work. But more than its reception, he is still concerned with its status as a moral instruction (pouchenie) to the world. He wishes now that his reader, one apparently superior in knowledge and experience than he, constitute the next iteration of the text with him, perhaps even for him. Gogol wishes that each successive edition of Dead Souls be better than the last: "Honestly can I say that to consider these points [gathered by my readers for me] against

23 N. V. Gogol, Dead Souls, trans. D. J. Hogarth (London: J. M. Dent and Sons, 1931), 1.

24 Gogol, Dead Souls, 2. 
the time when a new edition of my book may be published in a different and a better form would give me the greatest possible pleasure." 25 Consequently, he begs his readers to compose notes for his edification so that he might improve what has become, even without them, a classic. Desire and insecurity meet tragically in Gogol's introduction.

To secure his real-world wishes (rather than those of some authorial persona winking at us from the wings), Gogol tells his willing readers how to post their suggestions to him: "Inscribing the package with my name, let [my readers] then enclose that package in a second one addressed either to the Rector of the University of St. Petersburg or to Professor Shevyrev of the University of Moscow, according as the one or the other of those two cities may be the nearer to the sender." 26 Petersburg is where Gogol was teaching at the time he wrote his preface. It was his real address. These were his authentic wishes.

Gogol's preface is not a game, it is not relieved by Lermontovian irony, and it is not addressed, like Bulgarin's, to a select well-established reader, but to everyone ("whosoever," "wheresoever" the reader might be). Within the Genette category of authentic authorial prefaces, Gogol's may be one of the most direct of direct forms of discourse we are ever to encounter. Its guilelessness tests severely the commonplace notion that implied authors and implied readers are as close as two actual parties (real author and real reader) ever get. But here we sense persona-less Nikolai Gogol thrusting himself face to face before living readers in an act of direct communion. In his belated preface to Dead Souls, Gogol's raw and troubled being obliterates rhetorical distances assumed to normally inhere in verbal art.

We find in Gogol's foreword another order of significance, another function of discourse to be enclosed within authentic authorial prefaces. In Gogol's dramatic display of mental fragility-which is well beyond any run-of-the-mill authorial anxiety or insecurity-we catch a glimpse of his imminent breakdown. We observe, too, the risk inherent in any aesthetic communication that attempts to breach the divide that separates readers and authors, particularly during the first decades of the nineteenth century when Russian literature struggled for an identity. Gogol's anxieties make those of Narezhny, Bulgarin, and Lermontov

25 Gogol, Dead Souls, 3 (my emphasis).

26 Gogol, Dead Souls, 4. 
seem paltry. ${ }^{27}$ But they flowed from his character, not from the condition created by engagement in verbal art.

By the 1850s many changes had been wrought in literature. Literary style had shifted toward omniscience, authoritativeness, and god-like perspectives on the issues of the day. Consequently, prefaces almost completely disappeared from major texts. Turgenev and Tolstoy did not invoke them in any of their varieties-authorial, allographic, or actorial; authentic, fictional, or apocryphal. But the form persisted to a degree. Alexander Herzen and Nikolai Chernyshevsky used authentic authorial prefaces to their fiction, Who is To Blame? (1845) and What is to be Done? (1863), respectively. Herzen's preface was penned more than a decade after his novel appeared in an expurgated edition. Its direct authorial address takes a matter-of-fact approach in recounting the history of his novel's publication. It is brief, informative, neutral in tone, and enlivened somewhat by the use of occasional literary anecdotes. ${ }^{28}$

Chernyshevsky's preface, by way of contrast, is more aggressive in its direct authorial discourse. Its author's insecurities are overtly presented, but assertively and as a matter of pride. As if it were merely a matter of will to accomplish the feat, Chernyshevsky turns defect into virtue: "But now that I've warned you that I have no talent whatever, you know that any merit to be found in my tale is due entirely to its truthfulness." 29 This kind of claim that abounds in the novel incensed Dostoevsky. It is surprising that Chernyshevsky's novel was as successful as it was given that it insults readers outright:

Yes, the first pages of my story reveal that I have a very poor opinion of my public. I employed the conventional ruse of a novelist: I began my tale with some striking scenes taken from the middle or the end, and I shrouded them with mystery. You, the public, are kind, very kind indeed and therefore undiscriminating and slow-witted. You can't be

27 For a more thorough treatment of Gogol's art and insecurities, see Anne Lounsbery, Thin Culture, High Art: Gogol, Hawthorne, and Authorship in Nineteenth-Century Russia and America (Cambridge, MA: Harvard University Press, 2007).

28 Alexander Herzen, Who is To Blame? A Novel in Two Parts, trans. Michael R. Katz (Ithaca: Cornell University Press, 1984), 45-48.

29 Nikolai Chernyshevsky, What is to Be Done?, trans. Michael Katz (Ithaca: Cornell University Press, 1989), 48. 
relied upon to know from the first few pages whether or not a book is worth reading. You have poor instincts that are in need of assistance.... My name could not have attracted you [to my novel]. So I was obliged to bait my hook with striking scenes. Don't condemn me for it: you deserve all the blame. It's your own simpleminded naiveté that compelled me to stoop to such vulgarity. But now that you've fallen into my hands, I can continue the story as I see fit without further tricks. ${ }^{30}$

But tricks are exactly what Chernyshevsky was into. He waylays the naive and unsuspecting, turning away the unwashed mass reader while simultaneously holding out an olive branch to those who prove willing to follow him. It was and is the appeal made by cult leaders. ${ }^{31}$ Engage in disparagement, then supply a route to enlightenment:

As far as the worth of its execution is concerned, you can confidently place my tale side by side with the most famous works of your wellknown authors. Perhaps you'd not do wrong to place it even higher than theirs! It certainly contains more artistry—rest assured on that point.

You may thank me. You so love to cringe before those who abuse you; so now you can cringe before me, too.

Yet there is among you, dear readers, a particular group of people-by now a fairly sizable group-which I respect. I speak arrogantly to the vast majority of readers, but to them alone, and up to this point I've been speaking only to them. But with the particular group I just mentioned, I would have spoken humbly, even timidly. There is no need to offer them any explanation. I value their opinion, but I know in advance that they're on my side. Good strong, honest, capable people-you have only just begun to appear among us; already there's a fair number of you and it's growing all the time. If you were my entire audience, there'd be no need for me to write. If you did not exist, it would be impossible for me to write. But you're not yet my entire audience, although some of you are numbered among my readers. Therefore, it's still necessary and already possible for me to write. ${ }^{32}$

30 Chernyshevsky, What is to Be Done?, 47.

31 For the many ways Chernyshevsky exploited behavioral codes to manipulate his readers, see Irina Paperno, Chernyshevsky and the Age of Realism: A Study in the Semiotics of Behavior (Stanford: Stanford University Press, 1988), 159-218.

32 Chernyshevsky, What is to Be Done?, 48-49. 
Like Gogol in his preface to the second part of Dead Souls, Chernyshevsky expresses a deep desire for an ideal readership, that is, one that coincides in its thinking with his vision of a new reality that he conjures in a performative act of utterance. Where Gogol failed, Chernyshevsky succeeded. Young readers flocked to him and his call for a new social order. As Irina Paperno puts it, "Chernyshevsky succeeded in promoting cultural mechanisms for ordering human reality and organizing individual behavior in an era of ultimate disarray, when 'everything came up for rearrangement." 33

Chernyshevsky's manipulations, both aesthetic and social, worked within radical circles, which Chernyshevsky ineptly portrayed, ironically, to great success in What is to Be Done? The response from Dostoevsky in both philosophical and literary terms came within two years with the publication of Notes from the Underground. We might surmise that Dostoevsky's suspicion of authentic authorial prefaces derives from his reception of Chernyshevsky, a barely qualified writer of fiction who takes the risks of speaking in one's own voice to new lows. Bulgarin looks like an old piker in comparison.

Dostoevsky, it turns out, was to use authentic authorial introductions only on rare occasions in his fiction. When he did turn to them, it was in a threshold form where both the print context in which the tale occurs and the reliability of the voice contained in the preface challenge the diverse range of possibilities we observe in Narezhny, Bulgarin, Lermontov, Gogol, and Chernyshevsky. More often, however, Dostoevsky found greater scope for his first words in what Genette labels fictional authorial and allographic introductions.

\section{II}

\section{FICTIVE AUTHORIAL INTRODUCTIONS}

An introduction that projects an imaginary figure as its author is a form attested widely in the Romantic period by the likes of Sir Walter Scott, Washington Irving, Nikolai Gogol and, it has been argued, if speciously, Alexander Pushkin. Walter Scott's Laurence Templeton of

33 Paperno, Chernyshevsky, 38. 
Ivanhoe (1820) is a famous case in point. ${ }^{34}$ Templeton, in fact, served as a model for many a Russian Romantic prose writer. Scott's Ivanhoe, for example, begins with Templeton's preface cum dedication in which the real author depicts both addresser and addressee, each as fictional as the dust that forms the latter's surname:

Dedicatory Epistle to The Rev. Dr. Dryasdust, F. A. S., Residing in the Castle Gate, York.

Much esteemed and Dear Sir, It is scarcely necessary to mention the various concurring reasons which induce me to place your name at the head of the following work. Yet the chief of these reasons may perhaps be refuted by the imperfections of the performance.... I fear I shall incur the censure of presumption in placing the venerable name of Dr. Jonas Dryasdust at the head of a publication which the more grave antiquary will perhaps class with the idle novels and romances of the day. I am anxious to vindicate myself from such a charge; for, although I might trust to your friendship for an apology in your eyes, yet I would willingly stand convicted in those of the public of so grave a crime as my fears lead me to anticipate my being charged with. ${ }^{35}$

If some level of anxiety runs through prefaces, we detect it in Scott's stepping out of his established role as poet into that of prose writer. This shift in literary mode may account for the fictive prefaces of his Waverley Novels. The literary crimes with which Templeton fears he might be charged merely mask Scott's concerns with his "crime" of altering his authorial persona from poet to prosaist.

Whatever the case may be, Scott's fictional authorial introductions to the Waverley Novels (in Ivanhoe as elsewhere) give way after a decade of deception to an authentic authorial preface. In it Scott outs his fictional counterpart and lays claim to his own work. In a preface of 1830, Scott writes: "The author of the Waverley Novels had hitherto proceeded in an unabated course of popularity, and might, in his peculiar district of literature, have been termed l'enfant gâté of success.

34 Scott's introductions have become artifacts in their own right; they have been liberated from the narratives they introduce. See Walter Scott, The Prefaces to the Waverley Novels, ed. Mark A. Weinstein (Lincoln: University of Nebraska Press, 1978). For a study of Scott based in significant measure on his prefaces, see Caroline McCracken-Flesher, Possible Scotlands: Walter Scott and the Story of Tomorrow (Oxford: Oxford University Press, 2005).

35 Sir Walter Scott, Ivanhoe (Norwalk, CT: The Heritage Press, 1950), xvii. 
It was plain, however, that frequent publication must finally wear out the public favor, unless some mode could be devised to give an appearance of novelty to subsequent productions." ${ }^{36}$ No longer does Scott fear his readers' censure for turning from poetry to prose, for by 1830 he can rest assured that he, like his Templeton, is covered in Waverley glory. He signs his name to the introduction.

Scott's concerns shift from persona to pen, from authenticity to irony. He fears now that the Waverley Novels are becoming tedious. What better remedy, he claims, than to provide the "appearance of novelty" by providing a new type of introduction, as though prefaces held magical powers sufficient to rescue the narrative they introduce. Scott's jest comes at the expense of a naïve readership that has been mistaking Templeton for a real person for a solid ten years. Time has come for him to be rewarded for his accomplishment. Time, too, for readers to wise up. Time it was, too, for Scott to put his insecurities to rest, which he could now do with every assurance of success.

Scott spawned imitators of which there were many in Russia, some of whom were in fact tedious from the first words. Others were more clever. Nikolai Gogol belongs, of course, to the second camp. His Evenings on a Farm Near Dikanka, in which fictional authorial introductions appear, is a case in point. Part One (1831) and Part Two (1832) of the Dikanka Tales are introduced to readers by the beekeeper, Rudy Panko. Gogol's “author,” Rudy, takes solid shape before our eyes. ${ }^{37} \mathrm{We}$ learn about him from what he has to say about the narrators whose oral tales he transcribes. We also discover something essential about him from the editorial remarks he makes that dot the landscape of the tales he passes on to us. The social context in and through which the storytelling in the village of Dikanka takes place also gives us a sense of Rudy's character:

"What oddity is this: Evenings on a Farm near Dikanka? What sort of Evenings have we here? And thrust into the world by a beekeeper! God protect us! As though geese enough had not been plucked for pens and

36 Scott, Ivanhoe, ix.

37 Nikolai Gogol, Sobranie sochinenii v piati tomakh I (Moscow: Akademiia nauk, 1960), 11-303; The Complete Tales of Nikolai Gogol, vol. I, ed. Leonard J. Kent (Chicago: The University of Chicago Press, 1985), 3-206. 
rags turned into paper! As though folks enough of all classes had not covered their fingers with inkstains! ...."

I had a premonition of all this talk a month ago. In fact, for a villager like me to poke his nose out of his hole into the great world is-merciful heavens!- just like what happens if you go into the apartments of some fine gentleman: they all come around you and make you feel like a fool ... ${ }^{38}$

Rudy knows he is stepping beyond the social and literary boundaries that would normally apply to the likes of him. But he has a mission. And he has pretensions. The first is to bring a world hitherto unrepresented in Russian fiction to the fore, and the second to be the one to do it, literate, if lowly, beekeeper that he is. He knows (like his creator) that he has something new to present to the public. Furthermore, given that he is cognizant of his station in life and knows that his assumption of the author's mantle challenges social and cultural norms, he is aware that the reading pubic may not appreciate what he is up to:

At home, my dear readers-no offense meant (you may be annoyed at a beekeeper like me addressing you so plainly, as though I were speaking to some old friend or crony) — at home in the village it has always been the peasants' habit, as soon as the work in the fields is over, to climb up on the stove and rest there all winter, and we beekeepers put our bees away in a dark cellar. At the season when you see no cranes in the sky or pears on the trees, there is sure to be a light burning somewhere at the end of the village as soon as evening comes on, laughter and singing are heard in the distance, there is the twang of the balalaika and at times of the fiddle, talk and noise ... Those are our evening parties! ... ${ }^{39}$

It is in Rudy Panko's "hut" that the storytelling takes place. He describes the scene in his domicile-who listens, who narrates, how the audience responds to the stories, and how their spell is cast. ${ }^{40}$ Then Rudy concludes (in the preface to Part One of the collection) ${ }^{41}$ with an invitation to us, his readers, to come visit him so that we might enjoy more of the

38 Gogol, Complete Tales, 3; 11.

39 Gogol, Complete Tales, 4; 12.

40 Gogol, Complete Tales, 4-6; 11.

41 Each of the two parts of the Dikanka Tales is introduced by Rudy Panko. Gogol understood that a good deal of the charm of his tale had to do with Rudy's role, so he gave him full vocal range in the second part. 
same. He provides directions on how to find his hut and delivers up a long list of the foodstuffs with which we will be regaled upon arrival. ${ }^{42}$

There is no mystification in Gogol's prefaces. They are clearly fictional. The pleasures to be derived from them are direct. This is not to say, however, that the prefaces, particularly the first, are not rife with worries. Rudy Panko's anticipation of his readers' response to him as a writer is significant for being overt. Covertly, those anxieties may well stand in for Gogol's own, something of the type made in the extreme, as we have seen, in his introduction to the second edition of Dead Souls fourteen years later. His previous efforts at publication had proven disastrous, so much so that he either scorched the earth of his labor or consigned his manuscript to his desk to await a more propitious moment. All it took was the loud acclaim accorded his Dikanka Tales for Gogol to move on with alacrity. He issued Part Two within a year.

The second introduction reveals a voice more confident in its aesthetic purposes, more sanguine about the reader's response, and consequently less self-defensive and cautious. It plays on the strengths hard won in Part One:

Here is a second part for you, and I had better say the last one! I did not want, I did not at all want to bring it out. One should not outstay one's welcome. I must tell you they are already beginning to laugh at me in the village. "The old fellow has become stupid," they say, "he is amusing himself with children's toys in his old age!" And, indeed, it is high time to rest. I expect you imagine, dear readers, that I am only pretending to be old. Pretend, indeed, when I have no teeth left in my mouth! Now, if anything soft comes my way I manage to chew it, but I can't tackle anything hard. So here is another book for you! ${ }^{43}$

The mature Gogol is already apparent in the presentation of the narrator, whose speech engages in misdirection, allogism, slang, Ukrainianisms, and an orientation toward oral performance, all eventual stylistic trademarks. ${ }^{44}$

42 Gogol, Complete Tales, 7; 16-17.

43 Gogol, Complete Tales, 89; 137.

44 In Parts One and Two, Gogol's introductions include a glossary of Ukrainian vocabulary. 
But anxiety yet again sticks out its mug. In bidding farewell to his reader, Rudy Panko expresses a persistent fear of Gogol's-that he might be forgotten, never amount to anything, disappear without a trace: "Goodbye. It will be a long time before we meet again, if we ever do. But then, it would not matter to you if I had never existed at all. One year will pass and then another-and none of you will remember or miss the old beekeeper, Rudy Panko." ${ }^{45}$ Here questions concerning his ultimate value bedevil Gogol, barely masked as Rudy Panko. They presage the implosion we witness in the preface to Part Two of Dead Souls, an authentic authorial introduction that hardly obscures the ache of anxiety.

\section{III}

\section{FICTIVE ALLOGRAPHIC INTRODUCTIONS}

Allographic prefaces represent third-party introductions, that is to say, they are not written by the work's author, but by another party altogether. Allographic introductions include those written by real historical personages or by fictional personages. ${ }^{46}$ Of the two, Dostoevsky only uses the second subtype-fictional allographic prefaces. We examine two instances in which they occur in Russian literature of the Romantic period, Pushkin's Belkin Tales and Lermontov's A Hero of Our Time.

In taking up pen, ink, and paper to "poke one's nose out into the great world [of letters]," to cite Gogol's Rudy Panko again, there would seem to be little recourse for burying one's trepidation other than to hide behind a set of masks. In the direct authorial prefaces we have seen, Narezhny, Bulgarin, and Lermontov all wear their misgivings in more or less full view. Fictional authorial forewords, likewise, are hard-pressed to hide authorial anxiety. Both Scott's and Gogol's trepidations can be adduced through the discourse of their fictionalized authorial characters.

45 Gogol, Complete Tales, 91; 140.

46 For example, see Prince Peter Viazemsky's preface to Alexander Pushkin's “The Fountain of Bakhchisarai” (1824): http://feb-web.ru/feb/pushkin/critics/vpk/ vpk-152-.htm. 
Alexander Pushkin, cognizant of his own anxieties about turning from poetry, where his persona was well established, to prose, where it was not, attempted something different in his preface to The Belkin Tales (1831). He used a set of masks to filter out his authorial persona altogether. Like Scott, awaiting positive reader response before revealing himself to the public, Pushkin delivered up his story cycle anonymously. But, unlike Scott and Gogol, he did not present a fictional character who parades as the work's author. Instead, he provides a set of figures enrolled in the institutions of literature-a publisher, whose introduction we read; a collector of tales (who has literary pretensions), the eponymous Ivan Ivanovich Belkin; and four narrators, the "authors" of the tales that Belkin transcribes for publication. It is a complex structure that fictional allographic forewords more readily accommodate.

Pushkin's introduction follows the pattern of Scottian prefatorial mystification. Pushkin's fictional author, however, is not an author, like Templeton, but the publisher, “A. P.” Pushkin's initials suggested to critics and readers in 1831 that Alexander Pushkin was that very publisher. In other words, they viewed A. P. as Pushkin in the barest of disguises. A cursory reading of the introduction, however, convinces one rather quickly that the mentality represented in and through A. P.'s discourse does not, indeed cannot, point directly to Alexander Pushkin's identity. ${ }^{47}$

Pushkin hardly buries allusion to this fact. For example, A. P. promises to give us a thoroughly satisfactory account of Belkin's identity, the person who has transcribed the tales for posterity. To that end A. P. states that he will provide the entirety of Belkin's neighbor's epistolary account of him, the only reliable source of information he has on Belkin's character: "We print [the neighbor's letter describing Belkin] without any change or annotations, as a precious document testifying to a noble frame of mind and to a touching bond of friendship, and, at the same time, as a perfectly adequate biographical sketch." ${ }^{38}$ A. P.

47 This is not meant to suggest that Pushkin is not the author of The Belkin Tales. Here, I address the voice presented in the preface. It belongs to A. P., not to Pushkin, who has invented it for A. P. to use. Dostoevsky imitates Pushkin in Notes from the Underground.

48 A. S. Pushkin, Sobranie sochinenii v desiati tomakh 5 (Moscow: Khudlit, 1960), 45; Alexander Pushkin, Complete Prose Fiction, trans. Paul Debrezeny (Stanford: Stanford University Press, 1983), 62. 
nevertheless annotates the neighbor's letter, expunges parts of it on the grounds that it can be of little interest to the reader, and derives nothing from the letter that would allow either him or us to indeed perceive in Belkin "a noble frame of mind" or to find evidence of "a touching bond of friendship" between the letter writer and Belkin. ${ }^{49}$ Pushkin's clues are hardly subtle. But readers missed them nevertheless.

It cannot be said that either A. P. or Belkin is the author of the tales. A. P. merely discovers the manuscript of the tales (he doesn't explain how) and publishes it. Belkin, for his part, has merely recorded the tales. He did not invent them or write them down from direct experience. They are stories he has been told by four individuals whose identities we are excluded from knowing. ${ }^{50}$

In the introduction to The Belkin Tales Pushkin plays with reader curiosity about the relationship between authorial identity and authorial personae. Pushkin's preface parodies the assumption that authors are their characters in mufti. He also satirizes the reader's willingness to believe that fiction and life coincide, not only in the figure of the author, who mediates the two, but also in the figures of the dramatis personae. Critics' reviews in which A. P. was taken as Pushkin only fueled the satiric fire that warmed the only readers Pushkin seems to have cared deeply about-his friends, almost all elite literati. Pushkin could count on them to know who A. P. wasn't. ${ }^{51}$

Fictional allographic prefaces provide perfect cover for the author's identity. Any risks associated with "sticking your mug out" before the reading public can be effectively nullified by burying one's identity behind a set of narrative filters of the type Pushkin developed for The Belkin Tales. As we have seen in our treatment of authentic authorial prefaces, Mikhail Lermontov's pugnacious relations with readers led him to expose himself more than he might have wished. He might better have chosen to follow Pushkin's example of narrative layers in The Belkin Tales's first words. And, if not A. P., then Lermontov perhaps might have followed the model he embedded in his own novelthe "Introduction to Pechorin's Journal." 52 In Hero of Our Time,

49 Pushkin, Prose Fiction, 63-64; 46.

50 We are given their initials along with their station in life only.

51 Peschio, Poetics of Impudence, 94-124.

52 Lermontov, Hero, 63-64; 228-229. 
Lermontov parodies the conceit of having a traveling narrator discover a story that then finds its way into print. This traveler delivers up the first two tales of the five that comprise the novel. Like Panko and Belkin, Lermontov's traveler has acquired the first story, "Bela," from his temporary companion, a kavkazets, Maksim Maksimich. ${ }^{53}$ Then the traveler relates the second story, "Maksim Maksimich," which he narrates as a direct experience. At the conclusion of that second tale, the traveler describes how he acquired Pechorin's personal notes from Maxim Maksimich, who gives it up in a fit of pique. Pechorin's journal makes up the novel's last three chapters or stories. The traveling narrator provides an introduction to Pechorin's journal roughly mid-way through the novel. It represents a fictive allographic preface, structurally much like A. P.'s in The Belkin Tales but without creating the illusion of its coming from his (Lermontov's) hand.

Lermontov's novel is rather unique in that it contains two introductions. The first is in the normal place at the outset of the narrative (the late authentic authorial one I have already sketched). The second is the traveling narrator's inserted fictive allographic preface, allographic in the sense that Pechorin's journal is introduced to us by a third party who did not compose the text we are about to read, and fictive in that the speaker/writer is not a real, living third party.

The traveler's preface performs four functions. First, it introduces the text's genre-diary/journal. Second, in an attempt to verify the authenticity and reliability of the first-person narratives that comprise the journal, the traveler attests to the uncensored nature of Pechorin's confession: "While reading over these notes, I became convinced of the sincerity of this man who so mercilessly exhibited his own failings and vices. The history of a human soul, be it even the meanest soul, can hardly be less curious or less instructive than the history of an entire nation-especially when it is the result of self-observation on the part of a mature mind, and when it is written without the ambitious desire to provoke sympathy or amazement. Rousseau's Confessions have already the defect of his having read them to his friends." ${ }^{44}$ In other words, the traveler would have us believe that Pechorin did not write his notes for

53 A kavkazetz was a Russian common soldier who had served so long in the Caucasus that he had become bi-cultural.

54 Lermontov, Hero, 63-64; 229. 
public consumption. At the moment of his recording a diary of his life in the Caucasus, Pechorin is both author and sole audience, enclosing communication in a solipsistic circle very much in keeping with his personality and in his self-absorbed disregard of others.

Third, the traveler's introduction replicates the ironic stance of the preface Lermontov subsequently added. The traveler begins his preface saying, "I learned not long ago that Pechorin had died on his way back from Persia. This news gladdened me very much, for it gave me the right to publish these notes, and I took advantage of the opportunity to sign another man's work with my own name. God grant that readers do not castigate me for such an innocent forgery." 55 These tightly packed first words underscore the irony that is the novel in its entirety-its play with genre expectations chapter by chapter, its scathing attitude toward human behavior that is cut from one thin cloth, its reorganization of the plot's chronology, its claim that it has nothing to teach through its depiction of casual immorality while simultaneously educating through negative example nonetheless.

Fourth, the traveler's introduction to Pechorin's journal clarifies that the novel, A Hero of Our Time, is his and his alone: "Perhaps some readers will want to know my opinion of Pechorin's character. My answer is the title of this book. 'But this is wicked irony!' they will say. I wonder." ${ }^{56}$ At this point the traveling narrator's stance and Lermontov's coincide, but not their status one vis-à-vis the other. The traveler is the fictional author of the novel, Lermontov the authentic one. But, if their respective ontological statuses differ, their purposes are one-the exposure of "all the vices of a generation."

There are other vices of "our time" exposed in the preface as well. They have to do with the legal status of the text within society. The traveler has patched together disparate elements of his own writings (his travel notes) along with Pechorin's travel journal. He overtly discloses the problem for writers of the time-they are not protected from theft. The traveler considers it a minor crime that he has affixed his name to Pechorin's own work. In this way another risk-filled feature of the institutions of literature come to the fore in the embedded fictional allographic preface we find here: theft.

55 Lermontov, Hero, 63; 228.

56 Lermontov, Hero, 64; 229. 
We have already seen the depiction of the sundry figures who constitute the literary moment-publishers, writers working to become authors, authors themselves, collectors of tales, oral storytellers and transcribers of oral tales, compilers, and editors. In various combinations they figure in the introductions we have examined. But in A Hero of Our Time Lermontov's traveling narrator announces forthrightly the problem of copyright, the legal ownership of one's own creation. It was a serious problem, as Prince Vladimir Odoevsky (1804-1869) attests in the introduction to his Russian Nights (1844) only one year before Dostoevsky entered the field.

In closing this chapter in order to turn to Dostoevsky's prefaces, it is worth noting Odoevsky's experience in regard to the theft of his work, something he did not consider, unlike Lermontov's traveling narrator, a minor crime. Writing a foreword to Russian Nights for an 1860s edition of his collected works, a foreword, incidentally, which did not appear in print until the twentieth century, he noted:

[Some] good people took advantage of the fact that my book had become a bibliographic rarity and on the sly began pilfering out of it whatever anyone needed in his art. Some followed the literary practice, that is, they borrowed in a very refined manner under various guises; some were less ceremonious and simply replaced the names of personages in my works by those of their own choice, changed the time and place of action, and claimed it as their own; there were also some who without further ado took, say, a whole story of mine in its entirety, called it a biography, and signed their name to it. There are plenty of such curious works wandering around in the world. For a long time I did not protest against such borrowings, partly because this particular kind of edition of my works seemed rather amusing to me. Only in 1859 did I consider it necessary to warn certain gentlemen about the possible consequences of their unceremonious fraud... Thus, the fate of my book was as follows: people pilfered it, distorted what they took, and abused it; and the majority of readers did not have any means of checking these frauds. All these reasons taken together, which are of such importance to a person for whom the rights and obligations of a literary man are sacred, have prompted me to proceed with a new edition of my works. ${ }^{57}$

57 V. F. Odoevskii, Sochineniia $v$ dvukh tomakh 1 (Moscow: Khudlit, 1981), 305-306; V. F. Odoevsky, Russian Nights, trans. Olga Olienikov and Ralph E. Matlaw (New York: E. P. Dutton \& Co., 1965), 22-23. 
When Dostoevsky published his first work of fiction, Poor Folk, in 1845 , he entered a print world fraught with dangers, not only of the type described by Lermontov in fiction and Odoevsky in truth of fact, but of the several types we have examined in the works from the first decades of the nineteenth century. Prefaces constituted an entry point not only into a given work of art but into the fictional enterprise itself. It is a hallway that leads to several doors at once: toward the complexities of the communication process (from writer's motivation to reader response, from misreadings to ideal forms of communion); toward the individual writers' psyches and the anxieties that accompany their forays into creativity; toward bombast and egocentrism as well as toward raw ambition and unsettling insecurity; toward the playground of verbal art and toward sometimes striking earnestness.

Little wonder then that Dostoevsky avoided prefaces completely in the 1840s. Not a single one of his publications prior to his arrest for seditious activity in 1849 is preceded by a foreword, preface, introduction, or prologue. ${ }^{58}$ This fact may be ascribed to the emergence of realist narrative tendencies in the 1840 s, but this rings hollow as an explanation. Clearly, including an introduction was a matter of choice for any author at this historical moment. Dostoevsky opted out, one can conjecture, because he was most interested in the narrative and its function independent of a prejudicial word from his (or another's) point of view. He clearly did not feel the urge to direct readers toward an understanding of genre. He let the text do that, feeling no need to interject his own voice between the reader and the text. The work would stand on its own without interference.

Nor did Dostoevsky wish to have another voice prepare readers for their entry into the text, neither the voice of a living third party, say for example his apartment mate, Dmitry Grigorovich (1822-1899), nor the voice of his text's narrator. Dostoevsky was not interested in prodding his reader to form an ideal relationship with him via the text, that is, to decode his text in complete accord with his intentions. He did not seek

58 There is one possible exception. In "A Faint Heart" ("Slaboe serdtse"), the fictional author belatedly refers to the first paragraph of his account as a foreword (predislovie). Dostoevskii, PSS, II, 16; Fyodor Dostoevsky, White Nights and Other Stories, trans. Constance Garnett (New York: Grove Press, Inc., 1960), 57. 
the protection of a high-placed addressee à la Bulgarin. Neither did he wish to communicate with a narrow readership as Pushkin did or with an intellectually challenged one as Lermontov felt he must. He simply chose to have his narratives stand on their own, naked.

In many ways, his decision was a courageous one that ran against the norms of the period (prerogative of the young artist). After his incarceration and exile from 1849 to 1859 , however, he altered his approach and made judicious decisions about the use of prefaces, introductions, and forewords. Again he went against the prevailing norms of a new generation of authors, including the realists Turgenev, Tolstoy, Goncharov, and Saltykov-Shchedrin, who eschewed prefaces for the most part. When Dostoevsky did turn to introductions, he invented hybrid forms out of the types we have encountered in the models available to him. We turn to his unique practice now. 